
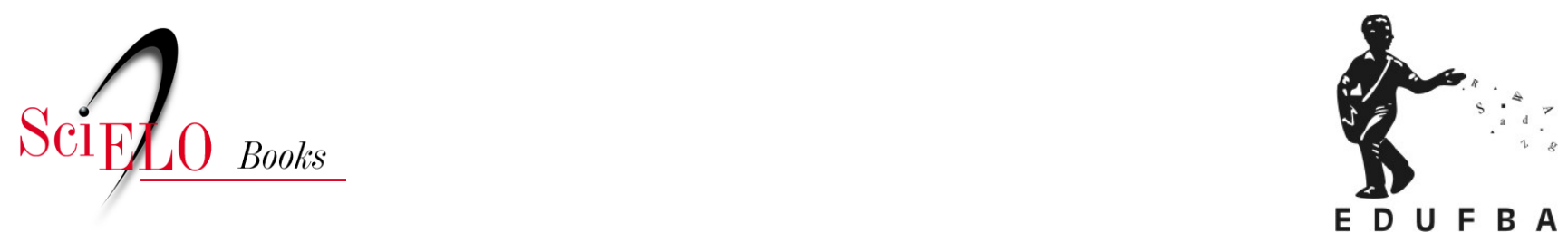

\title{
Pensar por associações
}

\author{
Maria Stella Bresciani
}

BRESCIANI, M.S. Pensar por associações. In: JACQUES, P.B., and PEREIRA, M.S., comps. Nebulosas do pensamento urbanístico: tomo I - modos de pensar [online]. Salvador: EDUFBA, 2018, pp. 18-44. ISBN 978-85-232-2032-7. https://doi.org/10.7476/9788523220327.0002.

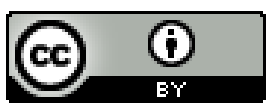

All the contents of this work, except where otherwise noted, is licensed under a Creative Commons Attribution 4.0 International license.

Todo o conteúdo deste trabalho, exceto quando houver ressalva, é publicado sob a licença Creative Commons Atribição 4.0.

Todo el contenido de esta obra, excepto donde se indique lo contrario, está bajo licencia de la licencia $\underline{\text { Creative }}$ Commons Reconocimento 4.0. 
PENSA R PO R 


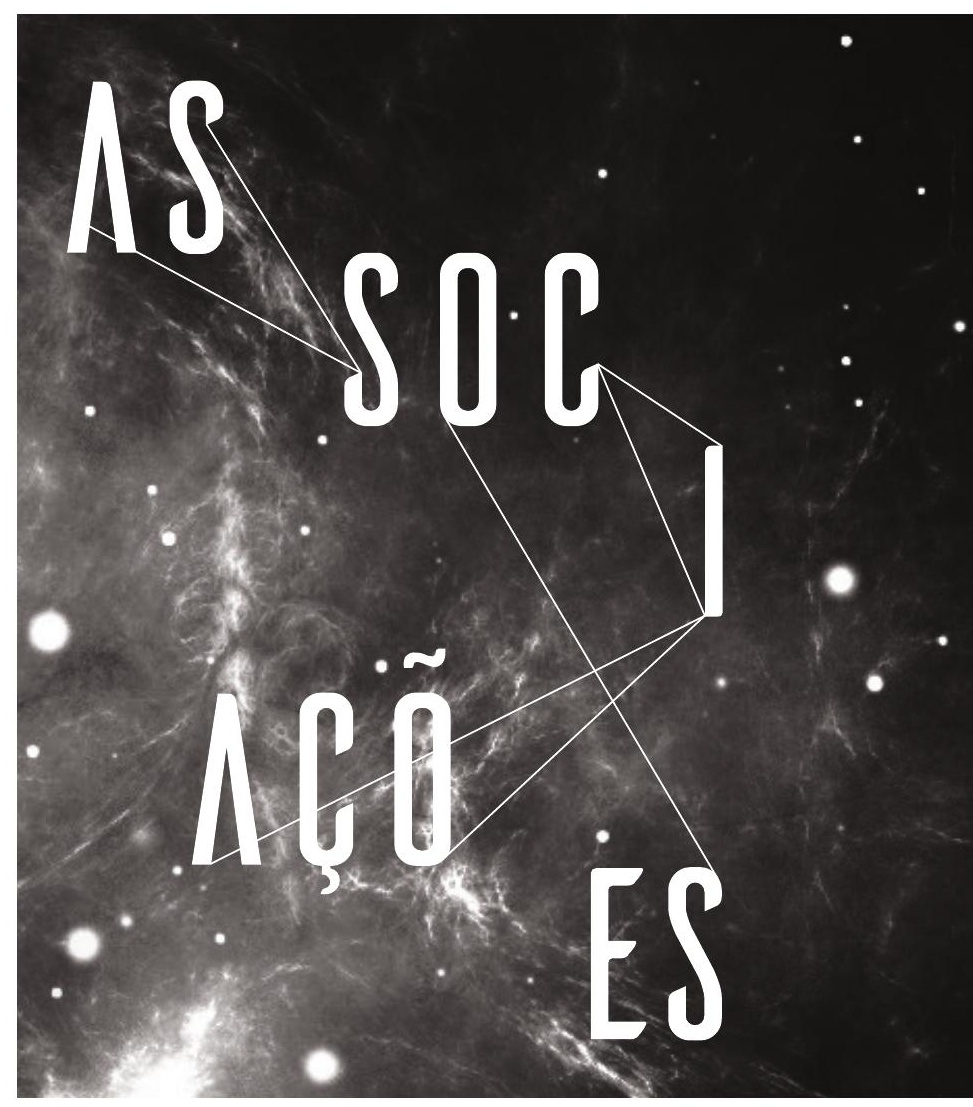




$$
\begin{aligned}
& \text { PENSAR } \\
& \text { P O } \mathrm{H} \\
& \Lambda S S O C I \Lambda \complement O E S^{\prime} \\
& M \wedge \cap \mid \wedge \\
& S T E L L A \\
& \text { B R E S C I A N I }
\end{aligned}
$$


azer associações é enveredar por um caminho tortuoso. Pode levar-nos a descaminhos, fazer transitar entre temas e disciplinas, a divagar entre escritos de natureza diversa e impor deslizamentos de conceitos para imagens e entre imagens de forte poder emotivo. Pode, em suma, nos conduzir por trilhas inusitadas, causar surpresas. Os descaminhos nos quais nos enredamos enriquecem a narrativa, porém a tornam sujeita a emboscadas perigosas. Fazer associações é um modo de pensar extremamente atraente e bem próximo ao que fazemos no dia a dia de nossas vidas. A atração que exerce pela proximidade entre a narrativa oral ou escrita e sua escuta ou leitura configura poderosa arma de sedução, de persuasão afetiva que se desloca, até sem nos darmos conta, para o convencimento racional.

Há narrativas explicitamente estruturadas por/ em associações e, dentre elas, dei prioridade às ficções literárias, por afinidade eletiva e intelectual. Nelas, a construção de personagens e as situações em que os autores os inserem configuram blocos de associações em que características pessoais colocadas em situação respondem à intencionalidade do argumento. Reside nesta associação a força emotiva da literatura ficcional ou romance: a aproximação do leitor com os personagens forma um vínculo subjetivo capaz de desfazer a distância entre ficção e vida efetiva. Não se pode, contudo, deixar de reconhecer a 
íntima correlação entre a escrita ficcional e outros textos dos quais se nutre e dos quais extrai seu poder de atração - escritos filosófi$\cos$, historiográficos, retóricos e estéticos, tratados morais e ensaios artísticos, por exemplo.

A opção por discorrer sobre o pensar por associações, neste texto, não poderia seguir outro percurso que não o próprio pensamento por associações. Desta opção, resultou o entrelaçar de escritos ficcionais e ensaios filosóficos, retóricos e estéticos, sem entrar em áreas com as quais não mantenho proximidade, tais como a psicanálise, o cinema e as artes plásticas.

Convido, assim, a uma deriva ${ }^{2}$ pela escrita literária motivada por enunciados da escritora e pensadora política Germaine de Staël, presentes em suas reflexões sobre a literatura, no livro De la littérature, publicado originalmente em 1800. Nele, os ecos dos anos revolucionários na França, fortemente marcados pelas reminiscências dos anos "do terror”, aguçavam sua sensibilidade, mas, ao invés de aprisioná-la no desencanto do mundo, levaram-na a uma aposta no poder dos escritos literários e políticos para atuarem na transformação dos costumes, na formação da civilidade e do civismo republicanos. (STAËL, 1991) O fundamento de sua dedicação à escrita se expressa nestas frases:

O homem tem, no segredo de seu pensamento um asilo de liberdade impenetrável à ação da força.

A literatura somente recolhe suas belezas duráveis da mais delicada moral [...] Estudar a arte de emocionar os homens, significa aprofundar os segredos da virtude.

A eloquência, o amor às letras e às belas artes, à filosofia, somente elas podem fazer de um território uma patria. ${ }^{3}$ (STAËL, 1991, p. 78, 68, 82, tradução nossa)

Seria, assim, próprio da trajetória da narrativa literária penetrar no "asilo da liberdade" (o foro íntimo), impenetrável à ação da força e da tirania; configurar e projetar imagens captadas pelos sentidos 22 para serem recolhidas pela reflexão e se fixarem como convicções 
morais-éticas. Staël (1991, p. 77) se detém nos procedimentos retóricos da "persuasão dos espíritos" e defende "o raciocínio e a eloquência" como "vínculos naturais de uma associação republicana", de "um estado democrático". Tem-se assim desenhada a estratégia amplamente utilizada pelos autores de romances para passar lições morais a seus leitores por meio do trabalho com os sentimentos. Se, como afirma Peter Gay (1988, p. 23), o mais marcante da experiência burguesa do século XIX foi a educação dos sentidos de modo a lidar com a própria ansiedade na busca por se autodefinir, o romance se apresentou como o veículo mais eficiente na formação da subjetividade de pessoas, cujas ocupações e nível de renda tão diversos mais causavam tensões e as desuniam do que formavam elos duráveis.

A observação de Gay se associa à de outro britânico que, entre os anos de 1757 e 1759, dizia a seus leitores: "Segundo me consta, as faculdades inatas do homem que se relacionam intimamente com os objetos exteriores consistem nos sentidos, na imaginação e no juízo". ${ }^{4}$ (BURKE, 1993, p. 23) Em escrito de juventude, publicado em 1757, o irlandês Edmund Burke trazia a público um ensaio filosófico sobre as noções estéticas do sublime e do belo a partir da leitura crítica de Do sublime, tratado de retórica e estética atribuído a Longinus. ${ }^{5}$ Para estabelecer conexões com o mundo, os sentidos faziam largo uso de metáforas associadas ao "gosto" (taste-paladar), que muito dependiam da experiência adquirida quando atribuíam qualificativos a alimentos, pessoas e situações. $\mathrm{O}$ autor cita como exemplos de consenso considerar o mel doce, o vinagre azedo e o aloé amargo; haver pessoas a quem atribuímos um "temperamento azedo" e falas qualificadas como "imprecações acerbas", ou ainda, definir trajetórias de vida como "um destino amargo". Já o sentido da visão, uma disposição natural em todos os seres humanos, seria menos complexo. Estaria, contudo, associado a uma "faculdade criativa própria ao espírito humano", a imaginação, designada por ele como “a mais ampla esfera do prazer e da dor". (BURKE, 1993, p. 23-26)

Seus argumentos deslocam-se, em seguida, das ideias apreendidas pelos sentidos e retidas na imaginação à "capacidade de comparar", por ela ser intrínseca ao processo de associar as propriedades específicas dos objetos a semelhanças e a diferenças. Dessa capacidade, decorriam 
duas funções da mente (mind) - o engenho (wit), ${ }^{6}$ ou a perspicácia de "notar semelhanças", e o juízo (judgment), cuja função seria a de encontrar diferenças. Ora, prossegue apoiado em John Locke: ${ }^{7}$ a mente humana sente maior satisfação ao encontrar semelhanças, pois com elas produz, cria novas imagens e amplia, desse modo, o estoque de ideias. Ato contínuo, Burke (1993, p. 27) remete a satisfação proporcionada pela faculdade do engenho aos "povos mais ignorantes e bárbaros", dentre os quais inclui "Homero e os escritores orientais", segundo ele, "admiráveis na descoberta de semelhanças, comparações, metáforas e alegorias, porém ineptos e lentos na distinção e classificação de suas ideias".

A separação entre imaginação-imagem e juízo-julgamento - a seu ver, atributos raramente unidos nas pessoas - estabelece nítida distinção entre o gosto natural, o prazer da semelhança que encanta a imaginação, e o gosto adquirido, o gosto crítico, princípio superior de homens que detêm maior conhecimento. Contudo, se sentidos e imaginação se vinculam diretamente às paixões sem o auxílio do raciocínio, as obras de imaginação poderiam deslizar para a esfera do juízo, se e quando fosse aperfeiçoado o hábito de raciocinar e, assim, estender seu poder persuasivo "até os costumes, às índoles, às ações e aos desígnios dos homens”. (BURKE, 1993, p. 27-31)

Há, entretanto, uma dimensão de grande interesse no ensaio de Burke. Após discorrer sobre as qualidades do sublime e do belo, ele nos convida, na parte $\mathrm{V}$ de seu ensaio, a compreender como agem nas mentes os efeitos das coisas detentoras dessas qualidades produzidas pelo homem. Exemplifica pela virtude, uma qualidade do espírito, pelo medo associado à escuridão, pela arquitetura, cujo efeito deriva das leis da natureza e da razão; detém-se, porém, longamente na influência das palavras e sentencia: "as palavras são tão capazes de incitar as ideias de beleza e do sublime quanto os objetos naturais e às vezes com um poder muito maior do que qualquer um deles". Maior poder tinham as palavras quando pronunciadas oralmente, já que a eloquência do orador produzia três efeitos no ouvinte: o som, a imagem ou representação e a afecção da alma causada por ambos, embora, por vezes, por serem abstrações, pudessem se abster das imagens. Atingiam a 24 ampla esfera dos sentimentos pelo forte poder de "partilhar paixões, 
de comover e fazer combinações que, conclui, de outro modo não seriam possíveis”. (BURKE, 1993, p. 169-181, grifo do autor)

Associar as noções do belo e do sublime aos cinco sentidos e ao poder das imagens em seu impacto na imaginação talvez possa ser rotulado de lugar comum ${ }^{8}$ no século XVIII. Para Burke (1993, p. 99, 48), seriam diversas suas fontes: o sentimento associado à noção do belo seria provocada por "aquela qualidade ou qualidades [puramente sensíveis] dos corpos em virtude das quais despertam amor ou alguma paixão semelhante"; por sua vez, o sentimento do sublime se associava "às ideias de dor e perigo, ao que de alguma maneira estivesse relacionado a objetos terríveis ou atuasse de modo análogo ao terror, a tudo, enfim, que produzisse a mais forte emoção de que o espírito fosse capaz"; no limite, poderia até "suspender o raciocínio”. Aliás, entre os moralistas britânicos ativos no século XVIII, encontramos referências explícitas às noções do belo e do sublime. Lorde Shaftesbury, no texto "Uma investigação acerca da virtude ou do mérito", publicado em 1711, estabeleceu a mesma relação entre a mente e os sentidos do olhar e da audição, capazes de nos fazer "discernir proporções, distinguir sons e perscrutar cada sentimento ou pensamento”. (SHAFTESBURY, 1996) Harmonia e dissonância, macio e áspero seriam atributos diferenciadores do belo e do sublime e configuravam representações de coisas sensíveis. Admiração e êxtase, aversão e desprezo se estenderiam para os objetos morais, que, como as imagens e as formas erradias de conduta fixavam-se na mente e impediam ao coração manter-se neutro. (SHAFTESBURY, 1996, p. 17-18)

A mesma correlação foi expressa por Francis Hutcheson em "Ensaio sobre a natureza e conduta das paixões e afecções", publicado em 1728. Para ele, nossas mentes receberiam, por meio de nossos sentidos, ideias provocadoras de prazer e dor sem a intermediação de nossa vontade. Seus argumentos estabelecem uma sequência de associações: os "sentidos externos" responsáveis pela percepção de objetos que, acolhida pelo "sentido interno", provocaria os "prazeres da imaginação"; já nossa sensibilidade para conceber, pela imaginação, uma dor real alheia configurava um "sentido público", aliado ao "senso moral", responsável por "percebemos a virtude ou o vício em nós 
próprios ou nos outros". A sequência completava-se pelos "sentidos de honra e de vergonha", correlatos da aprovação ou condenação de nossos atos. Suas reflexões, apoiadas no Livro IX da República de Platão, se estendem à necessária contenção das paixões pessoais e à aceitação da prevalência dos "calmos desejos públicos", relacionados a uma comunidade, e por ele extensivos à "calma benevolência universal". (HUTCHESON, 1996, p. 158-162, grifo do autor)

Esta deriva por dois dos vários intelectuais atuantes na produção de textos sobre filosofia moral no século XVIII - cujos escritos, por sua vez, remetem a vários outros, inclusive autores clássicos gregos e romanos - indica a ampla difusão dessas ideias entre a população letrada na língua inglesa e o compartilhamento de opiniões sobre a moral privada extensiva à ética pública, ou seja, à dimensão política do controle dos sentimentos fortes, das paixões. Esta preocupação perpassa todos os textos dos moralistas reunidos na coletânea Filosofia Moral Britânica. ${ }^{9}$ (BUTLER et al., 1996)

Cheguei aos moralistas e escritores britânicos do século XVIII conduzida por Germaine de Staël, quando, no Essai sur le fictions, publicado em 1795, explicitou a diferente importância dos livros dos moralistas para nos dar a conhecer nossos deveres e a dos romances para divulgá-los de modo mais eficaz. Dada a aridez didática do gênero, os escritos moralistas, afirmava a autora (STAËL, 1979, p. 39-40), mostravam-se insuficientes para adentrar as "nuances da delicadeza e detalhar os recursos das paixões”. Essa qualidade seria própria dos bons romances, como os de Richardson e Fielding, esses sim capazes de, pela trama narrativa, estimular "os movimentos interiores da alma" e, assim, passar "uma moral mais pura, mais elevada”. (STAËL, 1979, p. 47) Com essas palavras, Staël convidava seus leitores a se deter na importância das boas obras de ficção. A força da imaginação - "a faculdade mais preciosa do homem" - e a emoção propiciada pela trama romanesca, fortemente estruturada pelo caráter, bom ou mau, dos personagens e pelas situações por eles vivenciadas uniam-se para que delas se retirassem ensinamentos destinados a formar mores virtuosos. (STAËL, 1979, p. 41-43) Constituíam fonte essencial para inscrever a boa moral no foro íntimo e fazer dele deslizar para os costumes públicos. Dupla 26 fixação: como convicção afetiva e como certeza racional. 
Em longo ensaio sobre o poder das paixões - De l'influence des passions sur le bonheur des individus et des nations -, escrito entre 1793-1795, Staël (1979) associou os anos revolucionários na França ao período do radicalismo jacobino, vivenciados como "o reino do terror" ${ }^{10}$ Suas frases remetem "ao mais assustador período para o espírito público, à corrupção sem polidez” e ao "abuso, doença de alguns homens superiores, cujos espíritos limitados [...] os fizeram se sentir indiferentes à infelicidade dos outros". (STAËL, 1979, p. 57-58) Convicta de que "seria necessário despertar o desejo ao invés de ordenar a obediência”, traçava a trajetória do desejo, que, ao passar pelo crivo da razão, fixava-se como virtude e, assim, provocava o deslocamento do sentimento para a convicção. Seus argumentos projetam uma imagem poderosa: "o raciocínio e a eloquência são os vínculos naturais em uma associação republicana”, e saber coadunar a razão e a imaginação se mostrava qualidade indispensável aos homens que, chamados para o governo do Estado, deveriam deter "o segredo de persuadir os espíritos”. (STAËL, 1991, p. 66, 72-77)

Em seus textos críticos, as associações com ideias de outros autores se desdobram no modo como Staël compartilha com eles suas reflexões. Dentre as inúmeras remissões, selecionei os moralistas britânicos já citados, mais Fergusson e o pensador político e literato William Godwin, os franceses Bossuet, Voltaire, Marmontel, Condorcet, Rousseau e La Harpe, adicionados os alemães Kant e Goethe. Não há, entretanto, menção aos ensaios estéticos de Edmund Burke, autor citado em sua leitura crítica da Revolução Francesa, e de Kant, de 1764-1766, citado em seu texto Os conflitos das faculdades (1798). (STAËL, 1991, p. 58-60, 418)

Com o deslocamento para os textos da suíça-francesa Germaine de Staël, adentramos o período revolucionário iniciado em 1789 e os anos da expansão do exército francês para a Holanda e para além do Reno. Muito de seu ativismo nesse período provinha da convicção quanto à utilidade da escrita ficcional e seu poder de aproximar a narrativa à vida dos leitores, expressos na própria tessitura literária: "tudo é ao mesmo tempo inventado, nada é verdadeiro, mas onde tudo é verossimilhante”. (STAËL, 1979, p. 39) A essa convicção vinculou a escrita de dois romances importantes. Afinal, se imagens 
e sentimentos se associavam a convicções, cuja força persuasiva se mostrava muito mais poderosa do que o procedimento "seco" dos tratados morais, recorrer à escrita literária implicava impactar a imaginação de seus leitores e os convidar ao recolhimento da reflexão. Nesse movimento, a projeção imagética passava pelo raciocínio e fixava-se como certeza, convicção.

Por associar o grande poder das ficções à sua capacidade de emocionar e por estar convicta da importância e da necessidade de, no vazio deixado pelos acontecimentos revolucionários, formar os mores [princípios éticos] republicanos, Staël dedica sua escrita ao declarado intuito de animar corações e mentes a se voltarem para situações exemplares. Além de três contos de juventude e anteriores a 1789, "Mirza ou Lettre d'un voyageur", "Adélaïde et Théodore", "Histoire de Pauline" e o posterior "Zulma", de 1794, publicados postumamente em 1820, a autora exercitaria a ficção em dois grandes romances, Delphine e Corinne ou l'Italie, publicados em 1802 e 1807, respectivamente. Neles, a escrita ficcional estabelecia sua verossimilhança pela temporalidade em que a narrativa se inscrevia e pelas características atribuídas aos personagens. Com esse procedimento, a autora colocava em movimento emoção e razão, sentimentos e deveres, apresentados, muitas vezes, de modo conflituoso, como embates íntimos de seus personagens ficcionais.

Entrar na trama narrativa de Corinne ou l'Italie e de Delphine nos remete ao texto de Kant sobre o belo e o sublime que, tal como o de Burke, não é citado por Staël. Entretanto, as duas noções ressoam como um "lugar comum" nesse final do Século das Luzes e início do XIX e nos levam a uma pequena deriva de retorno a Burke associado a Kant, já que as observações deles sobre as características desses dois sentimentos se aproximam, embora guardem nuances e oposições. Para Burke (1993, p. 65-68), como indiquei acima, "os efeitos da paixão" causados pelo sentimento do sublime causavam o mais poderoso assombro e, ao colocarem em suspenso todos os movimentos da alma, bloqueavam o uso da razão; associavam-se intimamente ao sentimento do medo. Embora o autor indique certo grau de deleite, caso o medo e a dor não alcançassem uma grande intensidade, o sentimento do 28 sublime sempre implicaria a suspensão momentânea da reflexão. Já 
Kant aproximou o sentimento do belo ao do sublime e os considerou serem os sentimentos mais refinados, conquanto agissem de modo diverso. Aproximava-se da acepção de Burke ao associar o sentimento do sublime à visão de montanhas altíssimas ou a tempestades furiosas e o efeito provocado - o prazer misturado ao medo, acompanhado pela tristeza ou admiração silenciosa -, mas dele se distanciava ao vincular os dois sentimentos a qualidades morais pessoais de cada ser humano e aproximar o sentimento do belo à dignidade da natureza humana. (KANT, 1980, p. 451-453, 463) Já para Burke (19913, p. 99-100) seriam as qualidades dos objetos externos que, pelo contato com os sentidos, acionavam diferentes sentimentos nos indivíduos. Assim, para ele, o sentimento de beleza provinha do contato dos sentidos com as "qualidades sensíveis dos corpos que despertam amor ou paixão". Colocava, entretanto, em dúvida a afirmação do senso comum de ser o sentimento do belo provocado pelas exatas proporções das coisas, já que, para ele, "a beleza [tal como o sublime] não requeriam nenhum auxílio do nosso raciocínio". ${ }^{11}$

É, porém, imprescindível sublinhar os divergentes pontos de vista adotados por eles. Burke (1993) afirmava serem os sentidos, a imaginação e o juízo as faculdades inatas do homem e partia de um pressuposto: o de serem os objetos exteriores com suas específicas e diferentes qualidades acessíveis pelos sentidos, estes sim, iguais ou ligeiramente diferentes em todos os seres humanos. Detinha-se na faculdade criativa denominada imaginação por ser a única interessada pelas paixões sentidas por todos os homens sem o "auxílio do raciocínio”. Ou seja, somente quando as paixões estendiam-se até os costumes, às ações e aos desígnios dos homens é que suas virtudes e vícios deslocavam-se para a esfera do raciocínio, do juízo. Assim, pode-se entender que o objetivo de Burke (1993, p. 23-31) em sua investigação consistia em descobrir os "princípios pelos quais a imaginação é afetada e se era comum a todos os homens". Por seu lado, Kant, que afirmava ser seu texto antes o resultado do olhar do observador do que do filósofo, partia do pressuposto de que "as sensações do prazer ou do desprazer estavam menos na natureza exterior das coisas que as excitavam e mais na capacidade própria a cada ser humano de por elas ser tocado agradavelmente ou não". (KANT, 1980, p. 451) 
Esse pressuposto levou Kant (1980) a enumerar as gradações dos sentimentos do belo e do sublime na natureza humana, a lhes conferir qualidades intrínsecas e específicas, os dividir em sentimentos inatos e adquiridos e, ainda, a afirmar os sentimentos dizerem respeito ao homem em geral. Contudo, ele estabelece uma ampla variedade de caráter por sexo e por nacionalidade, sendo significativa a aproximação entre as várias gradações desses atributos definidas em suas observações quando associadas a perfis dos personagens masculinos e femininos e de diferentes nacionalidades nos dois romances de Staël. Para Kant (1980), seriam os italianos e os franceses os mais suscetíveis ao sentimento do belo, embora com características nuançadas; os ingleses, alemães e espanhóis mais se aproximavam do sentimento do sublime, em correlata graduação do sublime nobre, do magnífico e do fantástico; já os holandeses mostravam-se destituídos de sensibilidade refinada, ampliando a atribuição de diferenciado caráter aos árabes, persas, africanos e indígenas da América do Norte. Quanto aos sexos, suas observações ecoam lugares comuns: "não seria pueril dizer serem as mulheres o belo sexo" e ser sublime o caráter do sexo masculino, ou "sexo nobre"? Na sequência, desfia os sentimentos do belo, do gracioso, o prazer das belas roupas como qualidades próprias das mulheres que possuiriam, em termos quantitativos, inteligência igual à dos homens, diferenciada, entretanto, em bela inteligência e inteligência profunda para o sexo masculino, correlatas à bela virtude e à virtude nobre. Às mulheres, cabia se emocionar com objetos que tocavam os sentimentos de modo mais fino, deixados especulações ou conhecimentos abstratos, úteis, mas áridos, "à inteligência aplicada, sólida e profunda dos homens". Da prioridade concedida aos atributos do pensamento masculino, Kant (1980) concluía: "plenamente conscientes de sua inferioridade", consistiria mesmo "um gosto contra a natureza" levar mulheres a compartilhar com os homens o gosto das armas e das ciências. Podemos, sem dúvida, daí inferir os desdobramentos dessas diferenças quanto ao sexo se sobrepõem à nacionalidade das pessoas.

Esse pequeno desvio meio errante pelas observações de Kant cotejadas com as de Burke nos coloca novamente em contato com 30 Staël para examinar os personagens de suas ficções literárias. Em 
Corinne ou l'Italie, publicado em 1807, Oswald, lorde de Nevil, par da Escócia, personifica a ética racional britânica; contrapõe-se ao caráter de Corinne, poeta, escritora, improvisadora e uma das mais belas mulheres de Roma, caráter definido como "paixão reflexiva" (passion réfléchissante). Caracteres específicos somados ao clima e à temporalidade histórica dão lugar a associações polarizadas: o frio cinzento das ilhas britânicas e o brilho do sol da Itália, a situação política da Itália, mergulhada no passado do qual lhe restava unicamente "a glória das belas artes" e o poderio político e econômico do Império britânico presente e espalhado por boa parte do mundo; "os hábitos contidos do inglês”, sua introversão e menor interesse pelos objetos exteriores unidos ao sentimento do dever à pátria acima de tudo estabelecem contraste com a exposição pública dessa mulher dotada de dons artísticos e que "inspira aos italianos todos os talentos da imaginação”. (STAËL, 1985, p. 49-55) A atração apaixonada entre os dois se faz pelas diferenças de caráter; contudo, os contrastes se impõem quando a chamada ao dever faz o britânico Oswald se distanciar de Corinne, que, apesar de filha de pai inglês, herdara da mãe italiana os dons das artes e sua inclinação aos sentimentos.

Em Delphine, de 1802, embora os dois personagens sejam franceses, caráter e convicções formam outro par de oposições posto em jogo pela trama narrativa situada nos anos revolucionários e cujo ápice se localiza no período do Terror: a ética do Antigo Regime e seu código de honra contrapostos à ética dos princípios republicanos. ${ }^{12}$ Novamente, a mulher se apresenta como elemento desestabilizador. Delphine d'Albémar, educada nos preceitos liberais por um "tutor esclarecido e adepto das ideias filosóficas das Luzes”, só se conduzia por sua própria consciência; (STAËL, 1981, t. 2, p. 282) Léonce de Mondoville, de mãe espanhola, católica e adepta convicta dos costumes conservadores e pai nobre francês, se via preso aos laços familiares e à monarquia. Afastados pelos respectivos códigos éticos, unem-se pela paixão que os conduz à morte. Repete-se em Delphine a oposição de caracteres moldados por éticas diversas e incompatíveis, inconciliáveis, personagens unidos pela morte.

Nos dois romances, situados nos anos dos acontecimentos revolucionários na França, os conflitos se projetam nos personagens 
cuidadosamente construídos em seus perfis de caráter forte que, mesmo submetidos a intenso sofrimento, não se desvencilham dos pressupostos éticos nos quais foram criados. A narrativa tira sua força do embate da associação entre o poder dos sentimentos e as amarras dos costumes firmemente estabelecidos e do improvável deslocamento desses personagens atados a princípios, preconceitos e às rédeas sociais. Se Staël se aproxima do lugar comum sobre as características dos sexos e dos princípios éticos nacionais, explicitado nas observações de Kant, ela também segue a sequência: imagens - sentidos - imaginação - sentimentos, própria do "sensualismo britânico”. Essa sequência de noções atuantes nas mentes parece reinar no pensamento e procedimentos narrativos de vários escritores nesses anos finais do século XVIII e no século XIX.

Aqui, proponho mais uma deriva pela literatura ficcional, pois Charles Dickens nos introduz de modo direto, sem muitos rodeios, ao universo das relações mediadas pelos sentimentos movidos pelos interesses individuais, fortemente marcados pela formação da subjetividade burguesa: traça o perfil de Mr. Gradgrind simplesmente com as palavras com as quais interrompe a conversa de sua filha com o irmão Tom e a repreende: "Louisa, never Wonder!".

Esta advertência destinava-se a lembrá-la de que "a arte mecânica e o mistério para educar a razão passavam pelo bloqueio do cultivo dos sentimentos e afeições”. (DICKENS, 1982, p. 89) Em Hard Times (Tempos difíceis), Dickens (1982) fez de Mr. Gradgrind, pai de Tom e Louisa, professor responsável pela educação das crianças da cidade mineradora Coketown, um personagem saturado de predicados do utilitarismo, filosofia política e moral formulada em finais do século XVIII, atribuída ao filósofo e jurista inglês Jeremy Bentham. Tempos difíceis constrói, por associações entre personagens e situações, uma crítica irônica e mordaz aos pressupostos morais prevalecentes na sociedade britânica do século XIX.

Outra associação importante se faz por esse romance ter sido dedicado ao escocês Thomas Carlyle, pensador crítico do liberalismo e do utilitarismo benthamita, cujas ideias e projeções negativas da 32 sociedade industrial alimentaram boa parte do debate intelectual, 
social e político na primeira metade do século XIX, muito além das ilhas britânicas. Seus escritos sobre as características dos "tempos modernos" em Signs of the Times, de 1829, e sobre o movimento cartista em Chartism, de 1839, associavam os pressupostos utilitaristas, em seus desdobramentos legais e sociais, ao extremo individualismo, à difícil condição dos trabalhadores (working people) e à sua resistência e reivindicações por direitos políticos como projeção de potencial ameaça à sociedade civilizada. Carlyle se mostrou mestre em associações com figuras mitológicas e figuras da linguagem, em particular, as metáforas. Para criticar a crença nas estatísticas como belas abstrações inconclusivas, recorreu às Danaides da lenda grega. ${ }^{13}$ (CARLYLE, 1980) Seu foco associava duas noções: a precedência dada à racionalidade da produção, do lucro e à impessoalidade do chash nexus (vínculo monetário) em detrimento da convivência afetiva comunitária.

Na mesma trilha de Dickens, Carlyle lançou mão de noções do romantismo para associar o êxodo rural, a extinção da produção doméstica, seu ritmo e sua forma baseada em laços familiares à rápida substituição da variada destreza artesanal pelo movimento rítmico mecânico e repetitivo da atividade fabril, na qual cada minuto deveria ser obrigatoriamente dedicado ao trabalho. E a esse trabalho destituído de desafios, a destreza aplicada e atada a movimentos repetitivos acoplou a atmosfera sombria do ambiente fabril. Uma cadeia de associações que pode ser remetida ao liberal Adam Smith, atento, já em 1776, à necessidade de devolver pela educação formal o conhecimento e a criatividade, antes qualidades detidas pelo trabalhador artesanal. Com seu alerta, Smith (1983, p. 123) visava evitar - e a associação é significativa - que o trabalhador pobre inglês, considerado um ser inteligente, se tornasse, como resultado da "uniformidade de sua vida estagnada", um ser "tão embotado e ignorante quanto o possa ser uma criatura humana".

Mas voltemos à observação de Mr. Gradgrind: "Louisa, Never Wonder". "Wonder" associa-se à lembrança das Seven Wonders of the World, a condição de "maravilha" atribuída a sete objetos arquitetônicos do mundo antigo. ${ }^{14}$ Dentre os vários sentidos contidos no verbo "to wonder" - maravilhar-se, surpreender-se, ter dúvida e 
curiosidade sobre algo -, parece-me significativa a frase "We cease to wonder at what we understand” (Johson). (WEBSTER'S..., 1979) Ora, se deixamos de nos surpreender, maravilhar, de ter dúvidas e curiosidade quando passamos a entender o que causava impacto aos nossos sentidos, o cessar da surpresa pode ser entendido como um deslizamento da imaginação e dos sentimentos para a razão. Há, sem dúvida, nesse percurso da imaginação para o pensamento racional, a associação com a perda do brilho e da curiosidade quando se classifica e se atribui a algo um lugar no campo reticulado do conhecimento. Lá ele repousa e se fixa.

Fatos e números compunham o campo das certezas de Mr. Gradgrind e o mantinham alerta e preocupado com os livros disponíveis na biblioteca da cidade, repletos de contos de fadas, de gênios e outros personagens fantásticos. Deixemos de lado a expressão de infelicidade de Tom e Louisa em diálogos nos quais "I Wonder", mais aproximado das expressões brasileiras "eu acho", "eu creio" ou "eu penso", surgia com naturalidade. Em Tempos difíceis, ainda se pode associar a experiência da menina Sissy, cuja vida transcorria no circo entre cavalos adestrados por seu pai e sua incapacidade intelectual para explicar o que era esse animal, contraposta à rapidez com que seu colega de classe diligentemente sentenciou e classificou-o no campo do conhecimento erudito: quadrúpede, herbívoro, com 40 dentes etc. (DICKENS, 1982) Poderíamos correlacionar a situação novelesca a uma crítica ao esquematismo seco dos escritos moralistas, extensivo ao pensamento utilitário?

Há, entretanto, uma dimensão intrigante nas posições dos personagens utilitaristas de Tempos difíceis: a exclusão da imaginação, das surpresas e das dúvidas parece contradizer pelo menos um dos escritos de Jeremy Bentham, reconhecidamente fundador e divulgador do pensamento utilitarista. O recurso à imaginação se faz presente no decorrer da escrita de The Panopticon Writings (As cartas sobre o Panóptico), escritas em 1787, 1790-1791, texto que ganhou ampla divulgação ao ser analisado por Michel Foucault (1975) em Vigiar e punir. Nas cartas, Bentham (1995a) projetou por meio de palavras o edifício panóptico e concedeu enorme espaço à imaginação ao descrever nos mínimos detalhes 34 sua arquitetura. A diretriz - "não perder nenhuma oportunidade de 
falar ao olhar" - está presente em cada palavra que detalha os vários componentes da estrutura penitenciária, dispostos com racionalidade extrema, e mostrava ser possível a projeção imagética de "a new mode of obtaining power of mind over mind, in a quantitiy hiterto without example”. (BENTHAM, 1995b, p. 31)

A obtenção de poder da mente sobre outras mentes em quantidade até então desconhecida se fazia, contudo, por associar a criação ficcional de Deus ao guardião invisível, figurado como entidade onipotente, onividente e onipresente, sediado na obscuridade velada da torre central do edifício. O olhar firme e a voz do inspetor desubjetivados se dirigiam a cada prisioneiro individualmente em sua cela ou ao conjunto deles, mantendo-se sempre invisível. Essa presença efetiva configurava e se associava a uma figura imaginária poderosa e vários dispositivos completavam o ambiente. Sons estranhos, gritos e gemidos produzidos artificialmente, como se alguém estivesse sofrendo terríveis castigos físicos, o uso pelos prisioneiros de máscaras com expressões da gravidade das culpas, além da episódica exposição pública, atuariam como um "perpétuo pelourinho". Ou seja, a ideia da punição - mais ainda, o "espetáculo [imaginário] da punição" - consistia no dispositivo mais eficaz a ser associado ao terrífico, relacionado à penitência e à punição moral e física. Deveria agir sobre as mentes, aterrorizá-las, submetê-las à disciplina prisional sem o uso da força física. (BENTHAM, 1995b) A ideia de um possível castigo associado à dor física do sofrimento produzido pela projeção imaginária da dor cumpria a tarefa disciplinar.

Afinal, o próprio Bentham (1995b, p. 35) propõe aos leitores, já na carta II, o recurso à imaginação quando os incita a formar a ideia geral do edifício pela leitura do texto, antes de olhar a planta do panóptico projetado por seu irmão: "o edifício é circular. Os apartamentos dos prisioneiros ocupam a circunferência. Podem chama-las, se quiserem, as celas [...]". ${ }^{15}$ Toda a minuciosa e racional descrição do edifício e de suas partes componentes, a espessura das paredes e o afastamento das grades frontais das celas para impedir qualquer aproximação entre os prisioneiros, Bentham (1995b) a desloca para uma reflexão filosófica no texto "A Fragment on Ontology”, anexado a The Panopticon Writings. Em "Ontology”, o autor 
expõe as características das entidades - as perceptíveis, as reais e as ficcionais - e o modo pelo qual novas ideias são produzidas por meio da imaginação. Há, em seu texto, assim como na narrativa ficcional de Dickens, um deslizamento constante entre situações vivenciadas, verossimilhantes e imaginárias. O pensamento de Bentham trabalha por associações e ultrapassa o plano das sugestões ao afirmar de modo claro o poder da imaginação sobre as mentes. ${ }^{16}$

Sem pretender deslindar o emaranhado do campo da ontologia, designada por Bentham (1995b, p. 117) como a união da somatologia, "a ciência dos corpos", com a psicologia, "a ciência da mente", dele retiro sua observação sobre ser "o campo das entidades extremamente abstratas um labirinto não penetrado, um deserto até então nunca explorado". ${ }^{17}$ De início, as divide em perceptíveis e inferidas, bifurcadas cada uma em real ou fictícia. Sua definição das entidades perceptíveis imediatamente o associa a Burke e aos moralistas britânicos - por serem entidades cuja existência chegaria aos seres humanos pelo testemunho direto de seus sentidos, sem o apoio do raciocínio, isto é, sem reflexão. Elas seriam sempre um corpo, uma substância, palavra genérica e, diz ele, bifurcada ao infinito. Já as entidades inferidas não seriam apreensíveis pelos sentidos e sua existência, como a alma ou Deus, exigia o raciocínio para ser inferida. De seu lado, as entidades reais se referiam aos objetos designados por palavras, ou seja, a associação necessária e urgente que estabelecera a interlocução humana em seus primeiros estágios. Já as entidades fictícias seriam as faculdades e os poderes da mente e suas disposições - as exemplifica com a palavra "ideias" -, das quais nossa percepção é mais imediata e direta do que a das substâncias corpóreas, embora dependessem de modo incontornável de sermos persuadidos pelas palavras. Ou seja, deviam sua existência à lógica da linguagem discursiva. (BENTHAM, 1995b, p. 115-158)

Retenho dessas ideias pinçadas em "A Fragment on Ontology" (BENTHAM, 1995b) duas afirmações: as entidades perceptíveis nos chegam diretamente pelos sentidos, sem o recurso ao raciocínio/razão; as entidades fictícias devem sua existência à linguagem e ao raciocínio, à lógica, e são produzidas pela mente humana. Essas designações, ora menos, ora mais elaboradas, ora explicitadas, ora implícitas, percorrem 36 todo esse nosso caminho pelo uso das associações nos textos dos 
autores visitados neste artigo. As associações nos remetem às palavras iniciais de The Panopticon Writings quando Bentham (1995b) afirma estar propondo, por meio de palavras, um projeto, a arquitetura de "um novo modo de obter poder da mente sobre a mente, em quantidade sem exemplo até então”.

A materialidade da arquitetura atuaria diretamente sobre os sentidos dos prisioneiros sem passar pelo raciocínio, o que incluía a figuração da vigilância ininterrupta do inspetor. A materialidade das palavras usadas na descrição detalhada da penitenciária produz na imaginação do leitor uma projeção, um projeto ou uma imagem, apoiada em observações que lhe conferem sentido, na explícita intenção de Bentham de persuadir seus leitores quanto a sua exequibilidade e utilidade. Nas Cartas, há uma constante associação entre uma palavra-ideia e algo existente. A penitenciária, sempre explicitamente associada à penitência do ponto de vista religioso, também cumpria a função de, pelo arrependimento somado ao trabalho, produzir a ressocialização do condenado. A proposta da cela individual se associava à cela monástica, lugar de retiro isolado, próprio a induzir à reflexão; a introdução de instrumentos de trabalho na cela tinha a função de não dar alternativa ao trabalho contínuo e cumpria o objetivo de manter o prisioneiro ativo e produtivo, prepará-lo para um provável retorno ao convívio social; a torre central, cuja distância das celas se baseava em cálculo racional, figurava em termos materiais a vigilância permanente e projetava ficticiamente a representação de Deus associada ao aparente controle efetivo da mente do inspetor sobre as mentes dos prisioneiros.

Poderíamos prosseguir na associação entre os detalhes arquitetônicos da penitenciária e os efeitos esperados, apresentados nas Cartas escritas por Bentham em 1787 e nos anexos de 1791 e 1791, mas lembro que a aposta em sua eficácia completava-se pela produção fictícia do espetáculo da punição, a punição real substituída pela ideia da punição pelo sentimento do medo provocado pela dor associado à ideia da provável punição física. Enfim, nada seria mais próximo do sublime artificialmente produzido do que a associação entre a retórica da materialidade e a projeção retórica das palavras, tal como prescritas por Edmund Burke. A projeção da materialidade arquitetônica da 
penitenciária se aproxima de uma figura de linguagem extremamente útil na produção de imagens e sentimentos: a metáfora. $\mathrm{O}$ projeto da penitenciária figura em uma cadeia de imagens a metáfora da punição pela privação da liberdade, a vigilância contínua e penitência cotidiana.

As metáforas propõem mais uma deriva associativa, desta feita, a um dos textos do filósofo Paul Ricoeur sobre o processo metafórico. Mas nela se deter alongaria em demasia este texto já longo. Retenho somente a suposição principal do autor sobre a possibilidade e eficácia do recurso a metáforas estar vinculado à semelhança, e o momento pictórico ou icônico se relacionar à similaridade, como um desvio aceitável. Nas palavras do autor, "a metáfora não é o enigma, mas a solução do enigma”, (RICOEUR, 1992, p. 148) e lembro a figura das Danaides postas por Carlyle em paralelo à estatísticas para associá-las a trabalho inconclusivo. Esse seria o processo metafórico: uma aproximação entre ideias heterogêneas, operação sintética que age sobre a imaginação, tal como um insight dentro da semelhança, uma assimilação produtiva ou um "enxergar a semelhança apesar e através da diferença”. (RICOEUR, 1992, p. 150, grifo do autor) Fundava-se na habilidade da imaginação para produzir novos tipos por assimilação e produzi-los exatamente por meio das diferenças, sem eliminá-las; permitia formar a dimensão pictórica, o caráter figurativo da metáfora, que não se detém na figura mental de alguma coisa, mas expõe relações de uma maneira figurativa. No texto, Ricoeur ensina que o significado verbal gera imagens que rejuvenescem e restabelecem os traços da experiência sensorial e nos lança a uma psicologia da imaginação produtiva. (RICOEUR, 1992) Com esses primeiros passos do processo metafórico, desejo sugerir o quanto recorremos a metáforas e elaboramos associações em nosso cotidiano e lembrar sua eficácia para a inter-relação comunicativa.

Mas há ainda um pequeno ruído perturbador que me faz indagar sobre se, como seres urbanos, detemos as características de sermos menos sensíveis ao contato com o que nos é exterior, menos emotivos e mais racionais do que os que vivem em contato próximo com a natureza, uma oposição clara entre sociedade e comunidade, como 3 8 nos alertou Georg Simmel e, na sua trilha, Walter Benjamin fez 
importantes reflexões. Escolhi dois poemas de Baudelaire trazidos por Benjamin para dizer por imagens contrapostas e associadas a condição do ser urbano:

Cada um, nos acotovelando sobre a calçada escorregadia, Egoísta e brutal, passa e nos enlameia, Ou, para correr mais rápido, distanciando nos empurra.

Em toda parte, lama, dilúvio, escuridão do céu:

Negro quadro com que teria sonhado o negro Ezequiel.

(BAUDELAIRE apud BENJAMIN, 1989, p. 120)

Contraposto a esse outro poema em que o poeta fala dos sentidos do urbanita tão atentos com o que vê e que o emociona, é o tempo que foge num espaço nebuloso, tempo e espaço deslizam, se esvaem, sem se fixarem:

A rua em torno era um frenético alarido.

Toda de luto, alta e sutil, dor majestosa,

Uma mulher passou, com sua mão suntuosa

Erguendo e sacudindo a barra do vestido.

Pernas de estátua, era-lhe a imagem nobre e fina

Qual bizarro basbaque, afoito eu lhe bebia

No olhar, céu lívido onde aflora a ventania,

A doçura que envolve o prazer que assassina.

Que luz... e a noite após! - Efêmera beldade

Cujos olhos me fazem nascer outra vez,

Não mais hei de te ver senão na eternidade?

(BAUDELAIRE apud BENJAMIN, 1989, p. 117)

Como disse no início: fazer associações é enveredar por um caminho tortuoso. Pode levar a descaminhos, surpreender, nos aprisionar no labirinto das imagens verbais. Pode propor mais indagações do que respostas; incitar a prosseguir na senda das surpresas e descobertas, nos alertar sobre nada fixar ou cristalizar sob um rótulo. 


\section{NOTAS}

1 Este texto é parte da pesquisa Bolsa Produtividade do Conselho Nacional de Desenvolvimento Científico e Tecnológico (CNPq). (3.2015-2.2010).

2 Remeto à noção de deriva a partir do texto "Teoria da deriva” de Guy-Ernest Debord, do prefácio de Carlos Roberto Monteiro de Andrade e da apresentação de Paola Berestein Jacques, do livro Apologia da deriva: escritos situacionistas sobre a cidade, 2003. Desloquei a noção de deriva do espaço urbano para o espaço da(s) palavra(s).

3 L'homme a, dans le secret de sa pensée, un asile de liberté impénetrable à l'action de la force.

La littérature ne puise ses bautés durables que dans la morale la plus délicate [...]. Étudier l'art d'émouvoir les hommes, c'est approfondir les secrets de la vertu.

Léloquence, l'amour des lettres et des beaux arts, la philosophie, peuvent seuls faire d'un territoire une patrie...

4 Remeto todas as citações e referências à edição brasileira.

5 Há um mistério acerca da data e da pessoa de Dionisios Longinus ou Cassius Longinus, a quem se atribui Sobre o sublime, manuscrito grego e, tal como o autor, supostamente escrito no século X com edição impressa em 1554. Há dúvida sobre Dionisius e Longinus serem pessoas diferentes, e o manuscrito chega incompleto e teve sua tradução para o inglês com autoria de Dyonisius Cassius Longinus. O tradutor para o inglês afirma que se presume que sejam as traduções feitas a partir do assim denominado "the Paris manuscript", preservado na Royal Library at Paris (Remeto a Spurdens e Longinus, 1836, p. 3 e Longin, 1993, nota 1, p. 41).

6 Wit seria a habilidade de perceber conexões inesperadas entre ideias, coisas ou situações e expressá-las de forma breve, engenhosa e frequentemente aguda. (WEBSTER'S..., 1979)

7 Referência provável a An Essay concerning Human Understanding, publicado em 1690 e que mereceu rápida tradução em francês no ano de 1700 .

8 Emprego aqui a noção de lugar comum na acepção proposta por Miriam Revault D’ Allonnes (1999, p. 9): "Les lieux communs ne sont pas seulement des clichés ou des poncifs. Ils sont aussi les lieux du 'commun', le fonds ou s'échangent les paroles, les croyances, les préjugés, les arguments et les opinions de la cité réelle”.

9 Na apresentação da coletânea, Roberto Romano expõe a intensa presença dos moralistas ingleses em autores da Europa continental, exemplificados por ele em Kant, Rousseau e Diderot, tradutor de Shaftesbury. 
10 Sua crítica mais acerbada ao período jacobino se encontra nesse ensaio sobre a influência das paixões escrito entre 1793, quando exilada na Inglaterra, e 1795, já na Suíça. (STAËL, 1979)

11 Após discorrer sobre a beleza presente no mundo vegetal e animal não estar relacionada a medidas e proporções, Burke (1993, p. 107, 131) estabelece a crença nas "alardeadas proporções" a algo que dizia: "Há muito tempo se repetiu de trás para diante, de um escritor para outro, milhares de vezes, que as proporções dos edifícios foram estabelecidas com base no corpo humano", concepção que o tradutor supõe ser referência a Vitruvius.

12 Por ser um romance epistolar, salvo nas páginas finais, após a morte dos dois personagens Léonce e Delphine, as datas das cartas vão de 1790 a 1792.

13 Em uma das versões da lenda das Danaides, consta terem sido condenadas à tarefa eterna de encher com água uma vasilha sem fundo. A expressão é associada a um trabalho sem resultado proveitoso. (ENCYCLOPAEDIA, 1958, v. 7, p. 13)

14 Pirâmides do Egito, Mausoleu de Hakicarnasssus, templo de Artemis em Éfeso, os jardins suspensos da Babilonia, o Colosso de Rhodes, a estátua de Zeus de Fídias e o Farol de Alexandria. (WEBSTER'S..., 1979, p. 210)

15 A força da imaginação se apresenta tão poderosa nas Cartas que mereceu, em 1932, um livro de Charles Kay Ogden, Bentham's Teory of Ficitons (1932), e nos anos 1990, entre outros autores, Jacques Lacan (1994) fez várias referências à teoria das ficções de Bentham em Le Seminaire, no capitulo 8.

16 Bentham associa sua "simples ideia arquitetônica" ao "ovo de Colombo", um desvio importante de seu argumento. Mantém-se, porém, no campo da racionalidade utilitária quando finaliza sua última carta afirmando que a adoção desse único princípio mudaria toda a cena da face da sociedade civilizada: "a moral reformada, a saúde preservada, a indústria revigorada, a instrução difundida, os encargos públicos aliviados, a economia fixada como estivesse sobre uma rocha, o nó górdio das leis dos pobres, não cortado, porém desatado, tudo por meio de uma simples ideia arquitetônica”. (BENTHAM, 1995b, p. 95) Vale lembrar a introdução de instrumentos punitivos e pedagógicos na proposta de Bentham para a penitenciária, dentre os quais, estava a treadwheel - um moinho movido por pessoas ou animais por meio de degraus móveis ou por uma esteira; consistia em um dos castigos impostos aos prisioneiros. Esse dispositivo punitivo foi utilizado em penitenciárias da Grã Bretanha. (IGNATIEFF, 1978, p. 176-178)

17 "The Field of Ontology, or as it may otherwise be termed, the field of supremely abstract entities is a yet untrodden labyrinth, - a wilderness never hiterto explored". 


\section{REFERẼNCI IS}

BENJAMIN, W. Sobre alguns temas em Baudelaire. In: BENJAMIN, W. Obras escolhidas III. Tradução de José Carlos Martins Barbosa, Hemerson Alves Baptista. São Paulo: Brasiliense, 1989.

BENTHAM, J. A Fragment on Ontology. In: BENTHAM, J. The Panopticon Writings. Londres: Verso, 1995a.

BENTHAM, J. The Panopticon: Writings. Londres: Verso, $1995 \mathrm{~b}$.

BURKE, E. Uma investigação filosófica sobre a origem de nossas ideias do sublime e do belo. Tradução, apresentação e notas de Enid Abreu Dobranszky. Campinas: Papirus: Ed. Unicamp, 1993.

BURKE, E. A Philosophical Inquiry into the Origin of our Ideas of the Sublime and Beautiful. In: BURKE, E. The Works of Edmund Burke. Londres: G. Bell \& Sons, LTD, 1913. v. 1, p. 49-182.

BURKE, E. Reflexões sobre na Revolução em França. Tradução de Renato de Assunção Faria, Denis Fontes de Souza Pinto, Carmem Lidia Richter Ribeiro Moura. Brasília, DF: UnB, 1982.

BURKE, E. Reflections on the Revolution in France. Harmonsworth: Penguin books Ltd, 1979.

BUTLER, J. et al. Filosofia moral Britânica: textos do século XVIII. Tradução de Álvaro Cabral. Campinas: Ed. da Unicamp, 1996. v. 1.

CARLYLE, T. Chartims. In: CARLYLE, T. Selected Writings. Harmondsworth: Penguin Books, 1980. p. 149-232.

CARLYLE, T. Signs of the Times. In: CARLYLE, T. Selected Writings. Harmondsworth: Penguin Books, 1980. p. 59-85.

D’ALLONNES, M. R. Le dépérissement de la politique: Généalogie d'un lieu commun. Paris: Flammarion, 1999.

DICKENS, C. Hard times: For these times. Harmondsworth: Penguin Books, 421982. 
ENCYCLOPAEDIA Britannica. Chicago: Encyclopaedia Britannica, 1958. v. 7.

FOUCAULT, M. Vigiar e punir: o nascimento da prisão. Tradução de Ligia L. Ponde Vassalo. Petrópolis: Vozes, 1977.

GAY, P. A experiência burguesa da rainha Vitória a Freud: a educação dos sentidos. Tradução de Per Salter. São Paulo: Companhia das Letras, 1988.

HUTCHESON, F. Ensaio sobre a natureza e conduta das paixões e afecções. Tradução de Álvaro Cabral. In: FILOSOFIA moral britânica: textos do século XVIII. Campinas: Ed. Unicamp, 1996. v. 1.

IGNATIEFF, M. A just measure of pain: The penitentiary in the industrial revolution. 1750-1850. Nova York: Columbia University Press, 1978.

KANT, E. Des observations sur le beau et le sublime. Tradução de Bernard Lotholary. In: KANT, E. Oeuvres philosophiques. Paris: Gallimard, 1980. v. 1, p. $452-523$.

LACAN, J. Le Seminaire: La relation d' objet. Paris: Seul, 1994. t. 4.

LONGIN, R. Du sublime. Tradução, apresentação e notas de Jackie Pigeaud. Paris: Rivages, 1993.

OGDEN, C. K. Bentham's Teory of Ficitons. Londres: Kegam Paul, 1932.

RICOEUR, P. O professor metafórico como cognição: imaginação e sentimento. Tradução de Franciscus W. A. Van de Wiel. In: SACKS, S. (Org.). Da metáfora. São Paulo: EDUC: Pontes, 1992. p. 145-166.

SHAFTESBURY, L. Uma investigação acerca da virtude ou do mérito. In: FILOSOFIA moral britânica: textos do século XVIII. Tradução de Álvaro Cabral. Campinas: Ed. Unicamp, 1996. v. 1.

SMITH, A. A riqueza das nações: investigações sobre sua natureza e suas causas. Tradução de Luiz João Barúna. São Paulo: Abril Cultural, 1983. v. 2.

SPURDENS, W. T; LONGINUS, D. C. On the Sublime: translated with notes original and selected and Three Dissertations, Disquisition I, II e III. Londres: Longman, 1836. 
STAËL, G. Corinne ou l'Italie. Prefacio de Simone Balayé. Paris: Gallimard, 1985.

STAËL, G. Delphine. Paris: Éditions des femmes, 1981. 2. v.

STAËL, G. De la littérature. Paris Flammarion, 1991. t. 1.

STAËL, G. Essai sur les fictions suivi De l'influence des passions sur le bonheur des individus et des nations. Paris: Ramsay, 1979.

STAËL, G. Mirza, ou lettre d' un voyageur: Adélaïde et Théodore, Histoire de Pauline e Zulma. In: STAËL, G. Oeuvres completes de Mme La Baronne de Staël: Paris: Treuttel e Würstz, 1820. t. 2, p. 216-372.

STAËL, G. Oeuvres complètes de Mme: La Baronne de Staë. Paris: Treuttel et Würstz, 1820.t. 2.

WEBSTER'S New Dictionary of the English Language. New York: Simon and Schuster, 1979. 